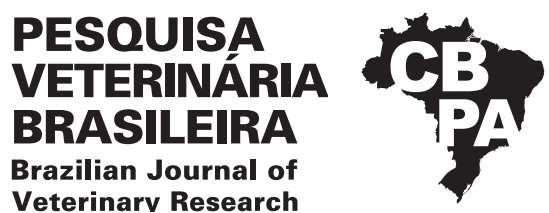

Pesq. Vet. Bras. 41:e06817, 2021

DOI: 10.1590/1678-5150-PVB-6817

Original Article

Livestock Diseases

ISSN 0100-736X (Print)

(cc) BY-NC

ISSN 1678-5150 (Online)

\title{
Attractivity of vinasse spraying to stable flies, Stomoxys calcitrans in a sugarcane area ${ }^{1}$
}

\author{
Taciany F. Souza², Paulo H.D. Cançado ${ }^{3 *}$ (D) and Antonio Thadeu M. Barros ${ }^{3}$
}

\begin{abstract}
Souza T.F., Cançado P.H.D. \& Barros A.T.M. 2021. Attractivity of vinasse spraying to stable flies, Stomoxys calcitrans in a sugarcane area. Pesquisa Veterinária Brasileira 41:e06817, 2021. Embrapa Gado de Corte, Avenida Radio Maia 830, Zona Rural, Campo Grande, MS 79106-550, Brazil. E-mail: paulo.cancado@embrapa.br

Stable fly (Stomoxys calcitrans) outbreaks have been associated with sugarcane mills in Brazil. This study aimed to evaluate the attractivity of vinasse, a liquid byproduct of ethanol production applied to postharvest sugarcane fields, to adult $S$. calcitrans. Stable fly abundance was monitored for 21 days in August-September 2014, at a sugarcane mill in the municipality of Nova Alvorada do Sul, state of Mato Grosso do Sul, Brazil. Following mechanized harvesting of sugarcane and the consequent deposition of large amounts of plant residue (straw) in the field, the study area (13.5ha) was surrounded by 22 sticky cylinder ("alsynite") traps. The area was fertigated with vinasse immediately after the traps were placed. Insects caught in the traps were collected daily at 7:00 a.m., 11:00 a.m. and 15:00 p.m. A total of 83,593 specimens of $S$. calcitrans were caught, of which 5,516 (6.6\%) were attracted within the first five hours after vinasse application. The highest number of $S$. calcitrans was caught in the first week following vinasse application, with a peak on the 4th day (12,818 flies), which was influenced by adverse weather conditions on the previous days. This study confirms that fertigation of sugarcane fields by spraying vinasse after the harvest attracts $S$. calcitrans, thus quickly increasing their abundance over the days following application.
\end{abstract}

INDEX TERMS: Stable fly, Stomoxys calcitrans, outbreak, vinasse, sugarcane mill.

RESUMO.- [Atratividade da aspersão de vinhaça à moscados-estábulos, Stomoxys calcitrans (Diptera: Muscidae), em área canavieira.] Surtos da mosca-dos-estábulos (Stomoxys calcitrans) têm sido associados a usinas sucroalcooleiras no Brasil. Este estudo objetivou avaliar a atratividade da aspersão de vinhaça, um subproduto líquido da produção de etanol aplicado após a colheita em áreas canavieiras, a adultos de $S$. calcitrans. A abundância desta mosca foi monitorada em uma usina de cana-de-açúcar por 21 dias, entre agosto e setembro de 2014, em Nova Alvorada do Sul/MS. Após a colheita mecanizada da cana e consequente deposição de grande quantidade de palha no campo, a área de estudo $(13,5$ ha) foi cercada com 22 armadilhas adesivas cilíndricas ("alsynite"). Fertirrigação com vinhaça foi iniciada imediatamente após instalação das armadilhas. A coleta das

\footnotetext{
${ }^{1}$ Received on February 26, 2021.

Accepted for publication on April 8, 2021.

${ }^{2}$ Faculdade de Medicina Veterinária e Zootecnia (FMVZ), Universidade Federal de Mato Grosso do Sul (UFMS), Av. Senador Felinto Muller 2443, Campo Grande, MS 79070-900, Brazil.

${ }^{3}$ Embrapa Gado de Corte, Av. Radio Maia 830, Zona Rural, Campo Grande, MS 79106-550, Brazil. *Corresponding author: paulo.cancado@embrapa.br
}

moscas capturadas nas armadilhas foi realizada diariamente às 7:00 a.m., 11:00 a.m. e 15:00 p.m. Foram capturados 83.593 espécimes de $S$. calcitrans, sendo 5.516 (6,6\%) atraídos nas primeiras cinco horas após a aplicação da vinhaça. Maior número de $S$. calcitrans foi capturado na primeira semana do estudo (53.937 moscas), com pico no 4o dia (12.818 moscas), influenciado pelas condições climáticas adversas ocorridas nos dias anteriores. 0 presente estudo confirma que o processo de fertirrigação de áreas canavieiras com aspersão de vinhaça após a colheita é atrativo à S. calcitrans, aumentando rapidamente sua abundância nos dias subsequentes à aplicação.

TERMOS DE INDEXAÇÃO: Mosca-dos-estábulos, Stomoxys calcitrans, surto, vinhaça, usina, área canavieira.

\section{INTRODUCTION}

Stable flies, Stomoxys calcitrans (Diptera: Muscidae), are hematophagous pests of livestock, wildlife, and man (Bishopp 1913). This species is one of the main ectoparasites affecting livestock in several regions of Brazil and around the world (Dominghetti et al. 2015, Cook 2020). 
Stable fly infestations lead to high economic losses to the cattle industry by affecting livestock productivity worldwide (Taylor et al. 2012). Moreover, stable flies are responsible for mechanical transmission of pathogenic agents (Baldacchino et al. 2013). According to Grisi et al. (2014), the annual losses to cattle production in Brazil caused by this fly surpass US\$ 335 million.

The immature stages of the stable fly develop in substrates containing decomposing matter including residues from vegetable crop production (Cook et al. 1999), agricultural production such as pineapple (Solórzano et al. 2015) and sugarcane (Bittencourt 2012, Cançado et al. 2013), and residues from cattle feed (Broce et al. 2005), particularly when mixed with animal waste. In Brazil, population outbreaks of stable flies have been associated with organic byproducts generated by sugar-alcohol mills, particularly filter cake and sugarcane straw wet with vinasse (Corrêa et al. 2013).

Vinasse is the liquid residue remaining after alcohol distillation and is one of the main byproducts of ethanol production; about 10 to 11 liters of vinasse are produced per liter of alcohol (Silva et al. 2007). Formerly, vinasse was routinely discharged into bodies of water and residue disposal areas, but these management practices were banned in 1978 due to environmental impacts. Such a prohibitions led to the practice of reusing vinasse for fertilization and irrigation of sugarcane fields in a process known as "fertigation".

Due to environmental concerns, the traditional preharvesting burn-off has been gradually replaced by mechanized harvesting since the late 1990's, resulting in a large amount of sugarcane straw over field areas. This change in the alcohol and sugar production process has been a key factor for occurrence of stable fly outbreaks over the past decade in several locations in southeastern and mid-western Brazil (Dominghetti et al. 2015).

Application of vinasse over the straw accumulated on the ground, usually by spraying, provides suitable conditions for development of immature stages of $S$. calcitrans thus leading to massive production of this fly in fertigated areas (Corrêa et al. 2013). The capacity for production of stable flies over the extensive areas covered by this type of substrate and its relationship to outbreaks in livestock farms adjacent to sugarcane mills is evident (Koller et al. 2009, Barros et al. 2010, Kassab et al. 2012). However, although baseline information on both the biology and the ecology of $S$. calcitrans under these conditions is essential for developing strategies to control this pest, such information remains scarce.

Observations from cattle ranchers and field technicians suggest perceptible increases in stable fly abundance in locations where vinasse is being applied or just after application. Thus, the present study had the objective of clarifying the response of stable flies to fertigation of harvested sugarcane fields with vinasse.

\section{MATERIALS AND METHODS}

Study area. The experiment was conducted from August to September 2014, on a commercial sugarcane field belonging to a

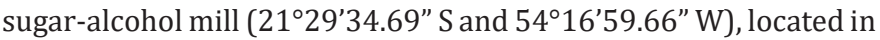
the municipality of Nova Alvorada do Sul/MS.

The farm where the study was carried out had a total area of 350 ha and was subdivided into 16 areas for sugarcane cultivation ("plots"). The experiment was conducted in plot number seven (19.5ha), and the study area measured 13.5ha. Areas around the study site were mostly sugarcane farms, cattle ranches, and dairies (Fig.1-2), but there was also a eucalyptus plantation and some soybean and corn crops.

Vinasse management. The study area was fertigated in accordance with the mill's vinasse application plan (VAP), with no changes due to the study. The fertigation process using vinasse, which was conducted by spraying using a hydraulic cannon (Fig.3), took place in the study site four days after the sugarcane had been harvested.

Vinasse application in the crop areas is routinely conducted in a continuous manner ( $24 \mathrm{~h} /$ day), depending on suitable weather conditions (absence of rain). The fertigation process began the previous evening, at least 700 meters apart from the study area and separated by unharvested areas of sugar cane; it was interrupted
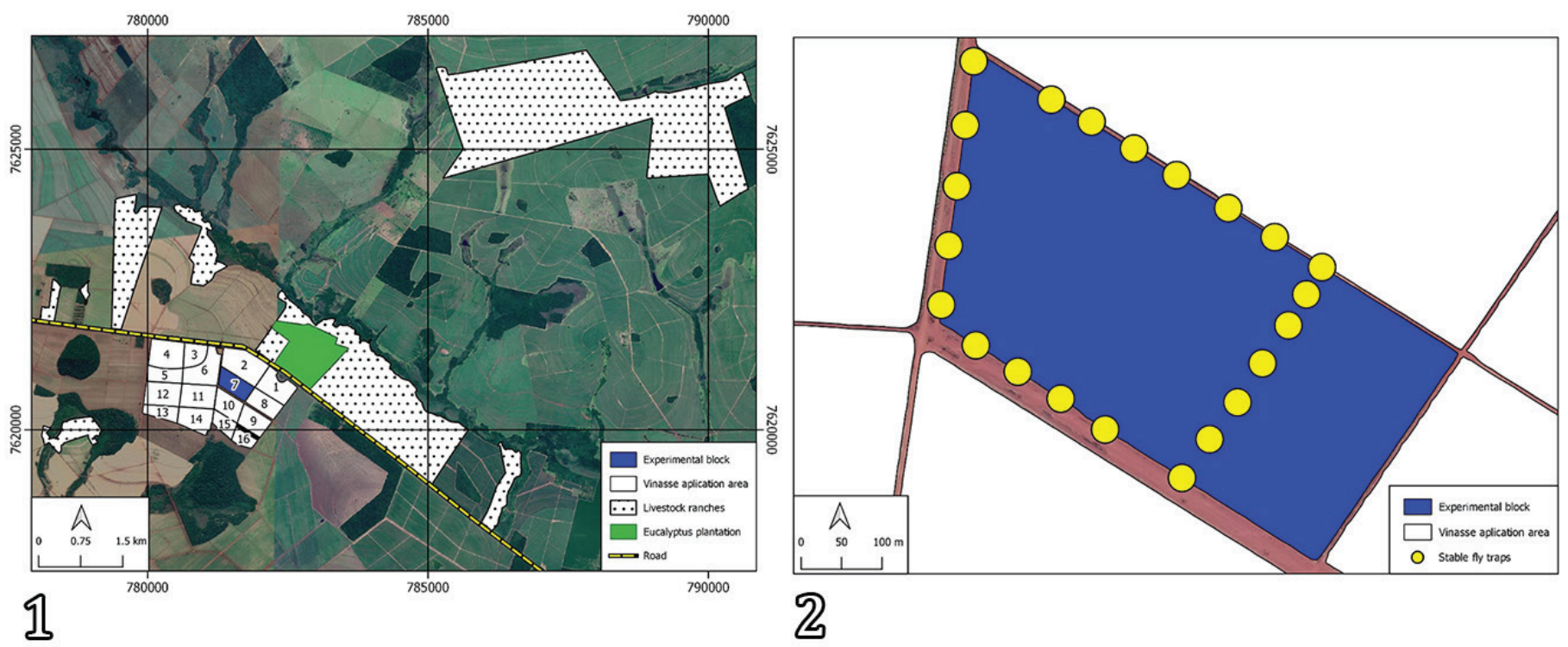

๘

Fig.1-2. Sugarcane experimental area and surroundings, highlighting the fertigated study area and distribution of stable fly traps, at Nova Alvorada do Sul/MS, Brazil. 
at the beginning of the following morning for trap installation, and restarted at 10:00 a.m., immediately after traps were set. A second vinasse application took place in the experimental area on the 11th day of the study. According to the vinasse fertigation report provided by the mill, five plots near the experimental area (100 to $300 \mathrm{~m}$ away) received vinasse applications during the study period: plots 1 and 2 (4th and 11th days), plot 8 (11th day) and plots 3 and 15 (17th day). According to the VAP of the mill, approximately $200 \mathrm{~m}^{3} \mathrm{ha}^{-1}$ of vinasse were applied to each plot during each fertigation episode.

Traps and fly collection. Sticky cylinder traps (Broce 1988) were used in the present study to assess stable fly abundance. These traps consisted of a piece of corrugated translucid fiberglass roofing sheet ( $40 \mathrm{~cm}$ in height $\mathrm{x} 22.3 \mathrm{~cm}$ in diameter) covered with a transparent adhesive plastic sleeve (ISCA Tecnologia Ltda.). Traps were fixed to wood stakes with their bottom $60 \mathrm{~cm}$ above the ground.

A total of 22 traps were installed from 8:00 to 10:00 a. m. around the experimental area (Fig.1-2). Traps were placed on average at $67 \mathrm{~m}(39-112 \mathrm{~m})$ from each other; most $(\mathrm{n}=18)$ between 57 and $80 \mathrm{~m}$ apart. Trap material was collected three times a day, at 7:00 a.m., 11:00 a.m., and 15:00 p.m., except on the first day when a single collection was carried out at 14:00 p.m. because of rain. Sticky sleeves with insects were sent to laboratory for Stomoxys calcitrans identification (Zumpt 1973) and counting.

During the whole study period, weather parameters were recorded daily in a meteorological station located at the mill's headquarters, about $11 \mathrm{~km}$ from the study area.

The study relied on local support and followed industry management schedules, which precluded prior trapping and daily collections at the study site because the short interval between harvesting and vinasse application. Thus, operational and logistic limitations did not allow to duplicate the methodology in a nonfertigated area. The results of this study were evaluated in relation to a concomitant stable fly monitoring (60 cylindrical traps) carried out continuously in several sugarcane areas nearby the study site. Such long-term monitoring (2013-2015) provided robust data on stable fly abundance in areas with and without vinasse application, as well as before and after fertigation with vinasse.

Statistics. The relationship between the number of stable fly specimens caught daily and the weather parameters of temperature and rainfall were analyzed using Pearson's correlation coefficient $(p \leq 0.01)$. The daytime activity of $S$. calcitrans was analyzed based on the frequency of flies caught at different times of the day, through

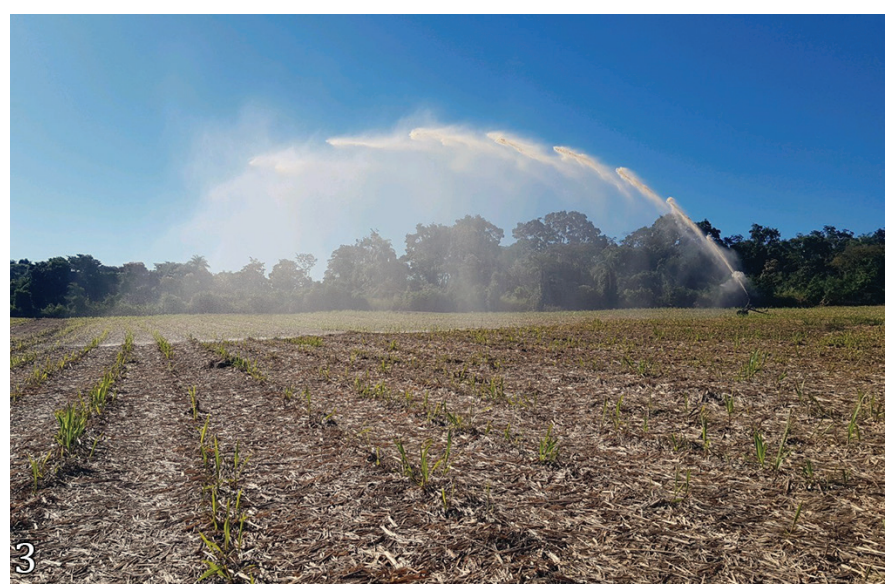

Fig.3. Vinasse spraying (fertigation) of a sugarcane field using a hydraulic cannon. the PROC FREQ analysis. All analyses were conducted using the SAS software (Statistical Analysis System 9.3/2011).

\section{RESULTS AND DISCUSSION}

During the three weeks of the study, a total of 84,410 Stomoxys calcitrans were caught. This represents a mean of 4,020 flies per day and 6,253 flies/fertigated hectare in the first three weeks following vinasse application. Continuous trapping (without daily collections) extended until the 29th day caught a total of 96,025 stable flies (245,3 flies/ha/day); if a similar abundance were to occur all over the sugarcane area that receives vinasse in a sugarcane mill, thus over seven million stable flies would be expected to be caught monthly for every thousand hectares of fertigated area. The high abundance of this fly observed in the present study was compatible with the findings of Corrêa et al. (2013) at another sugarcane mill.

Over the first five hours after traps were installed and the area was fertigated, 5,516 individuals were caught, thus demonstrating that adult $S$. calcitrans were quickly and highly attracted towards the vinasse. Such attractiveness has been shown through in vitro and field studies and has been attributed to the presence of various volatile compounds, such as carboxylic acids, alcohols, phenols, and aldehydes (Serra et al. 2017). A rapid inflow of $S$. calcitrans was also observed over the first hours after crushing the stems of pineapple plants (Solórzano 2014).

After the first insect collection from traps, adverse weather conditions for fly activity occurred over the first three days of the study. Thus, rain was recorded on the first $(8.2 \mathrm{~mm})$ and second $(1.5 \mathrm{~mm})$ days, as well as local winds $(13.2 \mathrm{~km}$ hour $^{-1}$ ) and an abrupt fall in mean temperature, dropping from $26^{\circ} \mathrm{C}$ on the second day to $14.1^{\circ} \mathrm{C}$ (minimum of $9.6^{\circ} \mathrm{C}$ ) on the morning of the third day.

Under such adverse conditions, a reduced activity and capture of stable flies due to rain and cold occurred until the morning of the third day of the study. A decrease in the abundance of $S$. calcitrans has been previously reported due to rain (Solórzano 2014) as well as to low temperatures (Semakula et al. 1989). Considering the high number of $S$. calcitrans caught over the first hours, higher capture rates would have been expected to occur over the following days after vinasse application if the adverse weather conditions had not limited this.

With the absence of rain and an increase in temperature over the third day, there was a notable increase in the number of stable flies caught on traps $(n=11,756)$. A subsequent peak of abundance was observed on the fourth day $(n=14,597)$. Although fly numbers decline after peak, the catches remained relatively high until the 7 th day, dropping after that (Fig.4). Similarly, attraction of stable flies to pineapple residues persisted for 6 to 7 days after cutting and grinding pineapple plants during harvesting (Solórzano 2014).

In addition to improving weather, the higher numbers of flies caught on traps on the third and fourth days may have been influenced by the process of substrate (straw with vinasse) fermentation in the study area, releasing attractive volatiles, and by the application of vinasse on the 4 th day in neighboring areas (plots 1 and 2), thus increasing the flow of flies nearby the experimental area. According to Oliveira et al. (2013), high $\mathrm{CO}_{2}$ production occurs during the initial process of straw and vinasse fermentation, with higher $\mathrm{CO}_{2}$ 
emission over the first six days following fertigation. Thus, the marked reduction in captures observed from the 6th day onwards (Fig.4) may be related to lower release of attractant volatiles, due to the continuation of the fermentation process.

In the week prior this study, mean catches from 32 traps distributed in non-fertigated sugarcane areas was 403.5 stable flies/trap, declining to 397.9 and 164.7 flies/trap in the following weeks. Such catches conducted in vinasse-free areas were much lower than fly numbers concomitantly caught in the first (2,637.0 flies/trap) and second (815.2 flies/trap) weeks after vinasse application in the present study.

In the long-term monitoring conducted the yearly average number of stable flies caught in both vinasse-free areas and in areas before fertigation during monitoring (Table 1) was always below that recorded in the two weeks after vinasse application in the present study. Mean stable fly catches during monitoring were consistently higher $(2.7 \mathrm{x}$ in 2013 , $2.6 \mathrm{x}$ in 2014, and 2.5x in 2015) in fertigated areas than in non-fertigated areas, and the highest number of stable flies in fertigated areas was about twice as high as in areas with no vinasse application (Table 1). The increasing stable fly abundance after fertigation and subsequent decline in the following weeks where observed in the experimental area and during the long-term monitoring, confirming previous anecdotal reports of cattle ranchers and field workers as well.

The analysis on the relationship between weather factors and the number of individuals caught in the traps varied according to the parameter addressed. During the study period, temperature was negatively correlated with the number of flies caught $(\mathrm{r}=-$ $0.56 ; p<0.01$ ). Although the correlation with rainfall was not significant, probably due to the low number of rain episodes, a lower frequency of flies caught on traps was found on the day after rainfall greater than $8 \mathrm{~mm}$ was recorded (Fig.4).

Wind may also affect the behavior of $S$. calcitrans, considering that they carried attractive stimuli to the flies (Gersabeck \& Merritt 1985). The dispersion of volatile compounds (originating from the process of applying vinasse and consequent fermentation) by winds, in association with the high stable fly capacity of dispersion (Eddy et al. 1962), resulted in rapid convergence of flies from adjacent areas, seeking sites to lay eggs in the experimental area. However, no relationship was observed between frequency of flies in

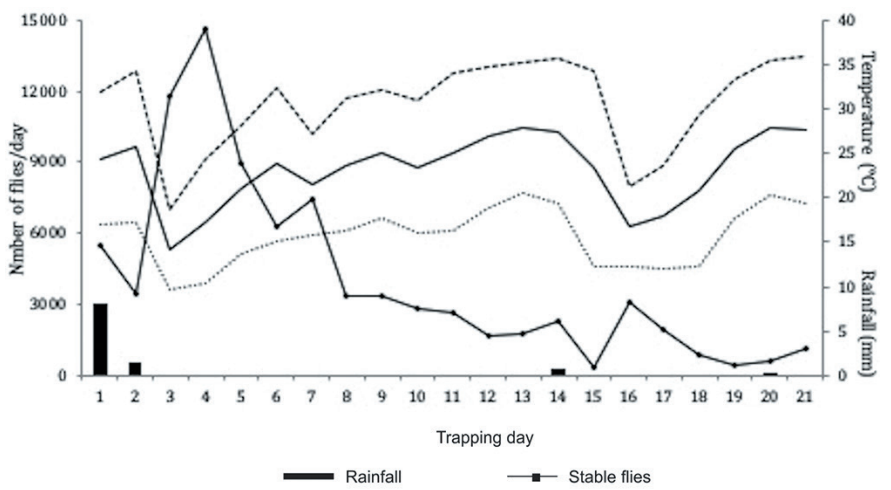

43 --.-- Max. Temperatura _ Avg. temperature …........ Min. Temperature

Fig.4. Daily catches of Stomoxys calcitrans in a sugarcane fertigated area and local weather records in August/September 2014, at Nova Alvorada do Sul/MS, Brazil. traps and predominant wind intensity or direction, regarding the locations of the livestock farms near the experimental area. The mean wind velocity, $9-12.3 \mathrm{~km} \mathrm{~h}^{-1}$, was lower than the limit of $16.7 \mathrm{~km} \mathrm{~h}^{-1}$ observed by Broce et al. (1991) for capturing $S$. calcitrans in similar traps.

Greater attractiveness of stable flies towards the experimental area occurred over the first week after vinasse application, when 58,014 (68.7\%) flies were caught. Over the following two weeks, catches gradually decreased and were respectively $17,935(21.3 \%)$ and $8,461(10.0 \%)$ individuals. The decrease was probably the result of changes in the composition of the substrate and the release rate of the volatiles from aging substrate (straw-vinasse) fermentation.

An important consequence of vinasse application is an increase in substrate moisture which would accelerate the fermentation process and hence the production of volatiles. When vinasse is incorporated into the soil, the organic matter is rapidly colonized by microbial decomposers (Silva et al. 2007) and the substrate degradation under intense microbial activity boosts the emission of gases such as $\mathrm{CO}_{2}$ and ammonia, which attract and stimulate oviposition of $S$. calcitrans (Jeanbourquin 2006).

The $\mathrm{CO}_{2}$ is an olfactive stimuli for hematophagous insects, which move towards its source, as observed for $S$. calcitrans (Guerenstein \& Hildebrand 2008). Considering that mechanized sugarcane harvesting followed by application of vinasse $\left(200 \mathrm{~m}^{3} \mathrm{ha}^{-1}\right)$ triples the emission of $\mathrm{CO}_{2}$ in sugarcane field areas (Oliveira et al. 2013), the fertigation of the experimental area with a similar volume of vinasse may have contributed towards increasing the inflow of $S$. calcitrans to that site.

The frequency of stable flies on traps varied markedly according to the time of collection (Fig.5), which ultimately reflected the fly activity under the predominant weather conditions over the catching intervals. Thus, the higher frequency of flies in the collections at 15:00 p.m. (11:00-15:00) in the first week can be explained by the lower temperatures during the early hours of the morning (below $13^{\circ} \mathrm{C}$ ) as well as in the late afternoon. Similarly, Gersabeck \& Merritt (1983) found higher stable fly activity after 11:00, which reflected local temperature conditions. Over the following warmer weeks (maximum temperatures above $30^{\circ} \mathrm{C}$ ), stable flies were active most of the day and collections tended to vary less dramatically, although always influenced by temperature changes.

The greatest number of stable flies caught per trap in a single day was 1,022 individuals. Besides changes in reflectance (Agee \& Patterson 1983), the efficiency of the sticky trap tends to decrease with the progressive reduction of the adhesive surface due to accumulation of debris and

Table 1. Yearly abundance of stable flies on traps placed in areas with and without vinasse spraying in post-harvested sugarcane fields in Nova Alvorada do Sul/MS, Brazil

\begin{tabular}{ccccc}
\hline \multirow{2}{*}{ Year } & Vinasse application & \multirow{2}{*}{ Number of traps } & \multicolumn{2}{c}{ Weekly stable fly catch } \\
\cline { 4 - 5 } & & & Average & Maximum \\
\hline 2013 & No & 33 & 54.8 & 387.8 \\
& Yes & 28 & 146.0 & 692.8 \\
2014 & No & 32 & 49.2 & 403.8 \\
& Yes & 29 & 126.1 & 877.2 \\
2015 & No & 33 & 40.9 & 157.6 \\
& Yes & 28 & 101.4 & 351.9
\end{tabular}




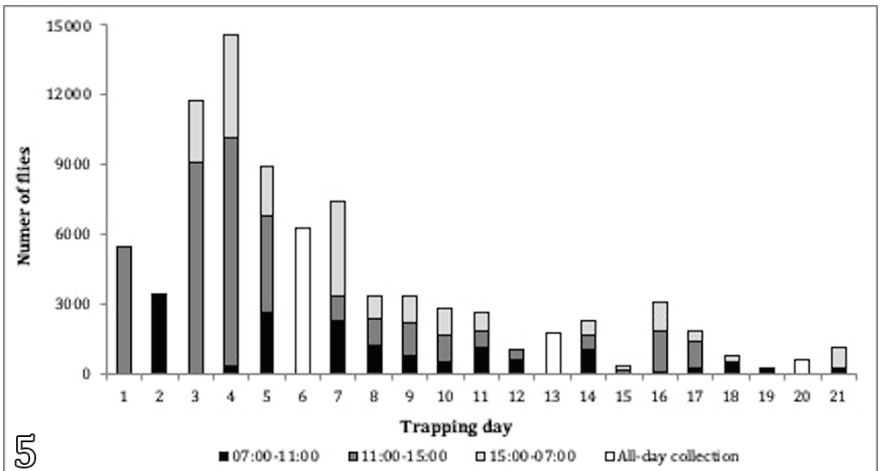

Fig.5. Absolute frequency of stable flies caught on sticky traps according to sampling time in a fertigated sugarcane area in Nova Alvorada do Sul/MS, Brazil.

dead insects. Thus, the capture of over 1,000 flies in a single day, as recorded in the present study, indicated that weekly monitoring tends to underestimate the actual abundance of stable flies in the site. Although an outbreak is already obvious in such situations, a shorter interval between insect collections from traps would be recommended if actual number of flies is important information.

The rapid inflow of flies after the application of vinasse suggested that flies were present in the vicinity and that, regardless of their origin, they were attracted by the volatiles released during application and/or fermentation of vinasse. Areas of tree/shrub vegetation, such as the eucalyptus plantation near fertigated plots and livestock areas, provided valuable shelters and therefore influenced the dispersion behavior of $S$. calcitrans around the study site.

The high numbers of $S$. calcitrans caught around a relatively small area recently fertigated demonstrated the high attractiveness of vinasse applied over the sugarcane straw. The same pattern of increased stable fly abundance after vinasse spraying has been extensively observed for years of long-term local stable fly monitoring. The development of $S$. calcitrans in sugarcane straw plus vinasse, combined with the vast extent of the area covered by this substrate, the attractiveness of vinasse, and the livestock activity in neighboring farms made these areas prone to massive production of stable flies and potential occurrence of outbreaks.

\section{CONCLUSIONS}

Spraying of vinasse attracts adult Stomoxys calcitrans, thus resulting in an immediate inflow of individuals to the fertigate sugarcane area.

Vinasse shows stronger attractivity to stable flies in the initial four days after spraying on sugarcane mulch, declining over the following weeks.

Acknowledgements.- The authors are grateful to the sugar-alcohol mill for allowing and supporting the study. The authors are also grateful to the "Fundação do Estado do Mato Grosso do Sul para o Apoio e Desenvolvimento da Educação, Ciência e Tecnologia" (FUNDECT) for its financial support, and to "Empresa Brasileira de Pesquisa Agropecuária" (Embrapa) for the infrastructure and resources that were made available. The authors are also thankful to Drs. Manuel Cláudio Motta Macedo and Gelson Luis Dias Feijó for the statistical support.

Conflict of interest statement.- The authors have no competing interests.

\section{REFERENCES}

Agee H.R. \& Patterson R.S. 1983. Spectral sensitivity of stable, face, and horn flies and behavioral responses of stable flies to visual traps (Diptera: Muscidae) Environ. Entomol.12(6):1823-1828.<https://dx.doi.org/10.1093/ee/12.6.1823>

Baldacchino F., Muenworn V., Desquesnes M., Desoli F., Charoenviriyaphap T. \& Duvallet G. 2013. Transmission of pathogens by Stomoxys flies (Diptera: Muscidae): a review. Parasite 20:26. <https://dx.doi.org/10.1051/ parasite/2013026> <PMid:23985165>

Barros A.T., Koller W.W., Catto J.B. \& Soares C.0. 2010. Surtos por Stomoxys calcitrans em gado de corte no Mato Grosso do Sul. Pesq. Vet. Bras. 30(11):945-952.<https://dx.doi.org/10.1590/S0100-736X2010001100008>

Bishopp F.C. 1913. The stable fly (Stomoxys calcitrans L.) an important livestock pest. J. Econ. Entomol. 6(1):112-126. <https://dx.doi.org/10.1093/ jee/6.1.112>

Bittencourt A.J. 2012. Avaliação de surtos e medidas de controle ambiental de Stomoxys calcitrans (Diptera: Muscidae) na Região Sudeste do Brasil. Revta Bras. Med. Vet. 34(Supl.1):73-82.

Broce A.B. 1988. An improved alsynite trap for stable flies, Stomoxys calcitrans (Diptera: Muscidae). J. Med. Entomol. 25(5):406-409. <https://dx.doi. org/10.1093/jmedent/25.5.406><PMid:3193434>

Broce A.B., Hogsette J. \& Paisley S. 2005. Winter feeding sites of hay in round bales as major developmental sites of Stomoxys calcitrans (Diptera: Muscidae) in pastures in spring and summer. J. Econ. Entomol. 98(6):2307-2312. <https://dx.doi.org/10.1603/0022-0493-98.6.2307><PMid:16539164>

Broce A.B., Schwenke J.R. \& Hampton K.E. 1991. Landing pattern of stable flies (Diptera: Muscidae) on the alsynite cylinder trap: effect of wind speed and direction. J. Med. Entomol. 28(5):730-733.<https://dx.doi.org/10.1093/ jmedent/28.5.730><PMid:1941944>

Cançado P.H.D., Ferreira T., Piranda E.M. \& Soares C.O. 2013. Sugarcane stems as larval habitat for the stable fly (Stomoxys calcitrans) in sugarcane plantations. Pesq. Vet. Bras. 33(6):741-744.<https://dx.doi.org/10.1590/ S0100-736X2013000600009>

Cook D. 2020. A historical review of management options used against the stable fly (Diptera: Muscidae). Insects 11(5):313. <https://dx.doi. org/10.3390/insects11050313>

Cook D.F., Dadour I.R. \& Keals N.J. 1999. Stable fly, house fly (Diptera: Muscidae), and other nuisance fly development in poultry litter associated with horticultural crop production. J. Econ. Entomol. 92(6):1352-1357. <https://dx.doi.org/10.1093/jee/92.6.1352><PMid:10633577>

Corrêa E.C., Ribas A.C.A., Campos J. \& Barros A.T.M. 2013. Abundância de Stomoxys calcitrans (Diptera: Muscidae) em diferentes subprodutos canavieiros. Pesq. Vet. Bras. 33(11):1303-1308. <https://dx.doi.org/10.1590/ S0100-736X2013001100003>

Dominghetti T.F.S., Barros A.T.M., Soares C.O. \& Cançado P.H.D. 2015. Stomoxys calcitrans (Diptera: Muscidae) outbreaks: current situation and future outlook with emphasis on Brazil. Revta Bras. Parasitol. Vet. 24(4):19842961. <https://dx.doi.org/10.1590/S1984-29612015079>

Eddy G.W., Roth A.R. \& Plapp Jr F.W. 1962. Studies on the flight habits of some marked insects. J. Econ. Entomol. 55(5):603-607. <https://dx.doi. org/10.1093/jee/55.5.603>

Gersabeck E.F. \& Merritt R.W. 1983. Vertical and temporal aspects of alsynite panel sampling for adult Stomoxys calcitrans (L.) (Diptera: Muscidae). Florida Entomologist 66(2):222-227.

Gersabeck E.F. \& Merritt R.W. 1985. Dispersal of adult Stomoxys calcitrans (L.) (Diptera: Muscidae) from known immature developmental areas. J. Econ. Entomol. 78(3):617-621. <https://dx.doi.org/10.1093/jee/78.3.617> $<$ PMid:4008745>

Grisi L., Leite R.C., Martins J.R.S., Barros A.T.M., Andreotti R., Cançado P.H.D., Pérez de León A.A., Pereira J.B. \& Villela H.S. 2014. Reassessment of the potential economic impact of cattle parasites in Brazil. Revta Bras. Parasitol. 
Vet. 23(2):150-156.<https://dx.doi.org/10.1590/s1984-29612014042> $<$ PMid:25054492>

Guerenstein P.G. \& Hildebrand J.G. 2008. Roles and effects of environmental carbon dioxide in insect life. Annu. Rev. Entomol. 53:161-178. <https:// dx.doi.org/10.1146/annurev.ento.53.103106.093402> <PMid:17803457>

Jeanbourquin P. 2006. The role of odour perception in the sensory ecology of the stable fly, Stomoxys calcitrans L. Doctoral Dissertation, Université de Neuchâtel, Neuchâtel.

Kassab S.O., Gaona J.C., Loureiro E.S., Mota T.A., Fonseca P.R.B. \& Rossoni C. 2012. Novos surtos populacionais de mosca-dos-estábulos no Mato grosso do Sul: medidas de controle e prevenção. Revta Agrarian 5(15):84-88.

Koller W.W., Catto J.B., Bianchin I., Soares C.O., Paiva F., Tavares L.E.R \& Graciolli G. 2009. Surtos da mosca-dos-estábulos, Stomoxys calcitrans, em Mato Grosso do Sul: novo problema para as cadeias produtivas da carne e sucroalcooleira? Documentos 175, Embrapa Gado de Corte, Campo Grande. 31p.

Oliveira B.G., Carvalho J.L.N, Carri C.E.P, Cerri C.C. \& Feigl B.J. 2013. Soil greenhouse gas fluxes from vinasse application in Brazilian sugarcane areas. Geoderma 200/201:77-84. <https://dx.doi.org/10.1016/j. geoderma.2013.02.005>

Semakula L.M., Taylor R.A.J. \& Pitts C.W. 1989. Flight behavior of Musca domestica and Stomoxys calcitrans Diptera: Muscidae in a Kansas dairy barn. J. Med. Entomol. 26(6):501-509. <https://dx.doi.org/10.1093/ jmedent/26.6.501 ><PMid:2585444>
Serra N.S.J., Goulart H.F., Triana M.F., Tavares S.S., Almeida C.I.M, Costa J.G., Santana A.E.G. \& Zhu J.J. 2017. Identification of stable fly attractant compounds in vinasse, a byproduct of sugarcane-ethanol distillation. Med. Vet. Entomol. 31(4):381-391.<https://dx.doi.org/10.1111/mve.12246> <PMid:28833391>

Silva M.A.S., Griebeler N.P. \& Borges L.C. 2007. Uso de vinhaça e impactos nas propriedades do solo e lençol freático. Revta Bras. Eng. Agric. Amb. 11(1):108-114. <https://dx.doi.org/10.1590/S1415-43662007000100014>

Solórzano J.A. 2014. Manejo integrado de la mosca del establo Stomoxys calcitrans en Costa Rica. Premio Innovagro 2014, Epi info [online]. Available at <https://www.redinnovagro.in/docs/INTA_crMosca.pdf > Accessed on Oct. 13, 2016.

Solórzano J.-A., Gilles J., Bravo O., Vargas C., Gomez-Bonilla Y., Bingham V. \& Taylor D.B. 2015. Biology and trapping of stable flies (Diptera: Muscidae) developing in pineapple residues (Ananas comosus) in Costa Rica. J. Insect Sci. 15(1):145.<https://dx.doi.org/10.1093/jisesa/iev127><PMid:26454479>

Taylor D.B., Moon R.D. \& Mark D.R. 2012. Economic impact of stable flies (Diptera: Muscidae) on dairy and beef cattle production. J. Med. Entomol. 49(1):198-209. <https://dx.doi.org/10.1603/me10050><PMid:22308789>

Zumpt F. 1973. The Stomoxyine Biting Flies of the World, Diptera: Muscidae: taxonomy, biology, economic importance and control measures. Gustav Fischer Verlag, Stuttgart, p.103-105. 